\title{
NONLINEAR STRUCTURAL ANALYSISBASED ON THE MODIFIED SEQUENTIAL LOAD METHOD
}

\author{
Vladilen V. Petrov \\ Saratov State Technical U niversity named after Y . Gagarin, Saratov, RUSSIA \\ Research Institute of Building Physics of the Russian A cademy of A rchitecture and B uilding Sciences, M oscow, \\ RUSSIA
}

\begin{abstract}
The article discusses ways to improve the accuracy of solving problems of nonlinear structural mechanics. It is shown that the combination of the method of sequential loading and the Newton-Kantorovich method can improve the accuracy of the solution and reduce the complexity of obtaining results. The solution of the given linear equations can be obtained by numerical and approximate methods known in the literature.
\end{abstract}

Keywords nonlinear mechanics, practical convergence, construction of an initial approximation, incremental equations, Freshet's derivative, Taylor series, abstract function.

\section{РЕШЕНИЕ НЕЛИНЕЙНЫХ ЗАДАЧ СТРОИТЕЛЬНОЙ МЕХАНИКИ МОДИФИЦИРОВАННЫМ МЕТОДОМ ПОСЛЕДОВАТЕЛЬНЫХ НАГРУЖЕНИЙ}

\author{
B.В. Петров \\ Саратовский государственный технический университет имени Гагарина Ю.А., г. Саратов, РОССИЯ \\ Научно-исследовательский институт строительной физики Российской академии архитектуры и строительных \\ наук, г. Москва, РОССИЯ
}

\begin{abstract}
Аннотация: В статье обсуждаются способы повышения точности решения задач нелинейной строительной механики. Показано, что сочетание метода последовательных нагружений и метода Ньютона-Канторовича позволяет повысить точность решения и уменьшить трудоемкость получения результатов. Решение приведенных линейных уравнений может быть получено известными в литературе численными и приближенными методами.
\end{abstract}

Ключевые слова: нелинейная механика, практическая сходимость, построение начального приближения, инкрементальные уравнения, дифференциал Фреше, ряд Тейлора, абстрактная функция.

A nalysis of the majority of applied research in nonlinear mechanics shows that the mathematical foundations used in them often fundamentally differ from the classical mathematics logic. For example, when investigating the stressstrain state of a real structure, the proof of the convergence of an infinite process of improving the solution or checking the fulfillment of the conditions of the corresponding theorem on convergence are replaced by the clarification of the approximate convergence of this process. For this purpose, it requires small number of steps to increase the accuracy. And if a clear tendency towards convergence is found, then the solution refining process stops. Thus, we replace the endless process of striving for an exact solution by a finite number of steps to obtain an approximate solution.

When solving nonlinear problems by approximate methods, both of two key problems always arise: the choice or obtaining of an initial approximation to the solution and the choice or creation of a converging iterative process, which allows refining the initial approximation. Since the solution of nonlinear equations is not known in advance and it is not always possible to indi- 
cate in advance the diameter of the region where it can be located, the problem of choosing an initial approximation often becomes essential.

It is known if the initial approximation belongs to the region of convergence of the iterative process, then the iterative process will converge to solving a nonlinear problem [1]. However, the radius of the convergence region changes during the process of solving a nonlinear problem with changing coefficients. For a weak nonlinearity, it is large enough. In this case, one can take the solution of a linear equation as an initial approximation, which is obtained by discarding the nonlinear terms in the original equations. For example, one applies this technique in framew ork of the method of elastic solutions [2] when solving problems based on the deformation theory of plasticity.

With an increase in nonlinearity, the size of the convergence region decreases, and the above method of the initial approximation obtaining can lead to the situation when it will be outside the convergence region. Then the use of an iterative procedure will generate a process converging to the convergence region boundary, and not to solving a nonlinear problem. In this case, it is necessary to organize the search for a suitable initial approximation. It should be borne in mind that in small neighborhoods of limiting points and bifurcation points, the convergence region decreases significantly and practically contracts to a point. In this regard, the problem arises of choosing or obtaining an initial approximation which falls into the region of convergence of the solution.

One of the methods for the approximate solution of nonlinear equations of solid mechanics is the sequential load method published in 1959 [3]. It allows one to obtain the solution of nonlinear problems by sequentially solving linear problems. This method is based on the principle of scientific determinism, which states that the subsequent states of a physical system are completely determined by its previous states. A detailed presentation of this method and its development for solving various problems of nonlin- ear mechanics of plates and shells can be found in the works [4 - 7].

The main idea of this method is quite simple. It is clear from physics if a load acts on a structure and causes large displacements or deformations, or both together, then the same stress and strain states of the structure can be obtained as follows. Let us imagine the load as a set of thin layers, the impact of each causes small deflections and deformations in the structure. At the first stage of the solution, we apply the first thin layer of the load and use the equations of the linear theory of elasticity to determine the stress-strain state of the structure. At the second stage of loading, we attach the second thin layer to the structure the deformations and internal forces of which is known from the first stage of loading. Then, second load layer causes additional small displacements and deformations, which are also determined from linear equations. Let us summarize the deformations and displacements found at the first and second stages of loading, and proceed to the third stage of loading with a small load layer. This process of sequential loading of the structure is repeated until the sum of the load layers reaches the specified value.

Durring the calculation process at each loading stage, we deal with a new computational linear system that has known deformations, forces and variable coefficients of linear equations from the results of previous loading. The advantage of the method is that in the process of calculations we determine the stress-strain state of the beam, plate or shell at all loads less than a given range, solving the similar recurrent equations. In addition, the procedure for constructing the zero approximation disappears. This approach to solving the problem is called incremental (from the word 'increment' that means an increase or addition, especially one of a series on a fixed scale).

The advantages of the sequential load method include the following. The principle of superposition is valid at each stage of loading. In the process of the problem solving, it is possible to determine the moment of appearance of plastic 
deformations or a change in boundary conditions (constructive nonlinearity) and change the design scheme of the structure. The sequental load method makes it possible to select from the set of real solutions of nonlinear equations such a solution that corresponds to a continuous change in the load. A s a result, we get a solution taking into account the loading history.

Incremental equations of the sequential load method can be obtained using the concepts and terminology of functional analysis. The set of equations of nonlinear solid mechanics or the resolving equation for a structural member under consideration can be written in the form of an operator equation:

$$
A(u)=p \quad \text { or } \quad A(u, p)=0
$$

Further, we restrict research area by studying the behavior of the solution to this equation when it changes the load parameter.

Let us accept $\mathrm{E}_{1}, \mathrm{E}_{2}$ - as linear normed Euclidean spaces, $A$ is a - nonlinear display from $\mathrm{E}_{1}$ to $\mathrm{E}_{2}$. $\mathrm{A}$ is a nonlinear twice differentiable positive definite operator of Frechet in the Hilbert space $\mathrm{H}$; $\mathrm{u}$ is the required element of this functional space. Operator $A$ is defined on a certain set of functions with domain of definition $D(A)$. The functions and their first derivatives are absolutely continuous in the region $\Omega$. Here $\Omega$ is the finite region of the coordinate space occupied by a beam, plate or shell. On the boundary $\Gamma$ of the region $\Omega$, the functions must satisfy the specified boundary conditions. The possibilities of using the operator form of equations for geometrically nonlinear problems are considered in the work [8]

Let us consider some fixed state $A\left(u_{0}\right)=p_{0}$. In an adjacent (perturbed) state caused by a small change in load, this equation takes the form

$$
A\left(u_{0}+\Delta u\right)=p_{0}+\Delta p
$$

where $\Delta \mathrm{u}$ is an arbitrary element of Hilbert space $\mathrm{H}$. Subtracting the original unperturbed equation from the perturbed equation, we obtain

$$
A\left(u_{0}+\Delta u\right)-A\left(u_{0}\right)=\Delta p
$$

Expanding the left part of this equation in a Taylor series in powers $\Delta u$, as a result, we obtain

$$
A\left(u_{0}+\Delta u\right)-A\left(u_{0}\right)=I\left(u_{0}\right) \Delta u+\omega\left(u_{0}, \Delta u\right)
$$

The first term of the right part of this equality is a linear function of $\Delta u$ which approximates the left part side up to values of the order of smallness that higher than the increment rate $\|\Delta u\|$.

$$
\text { If } \begin{aligned}
\left\|\omega\left(u_{0}, \Delta u\right)\right\| \cdot \llbracket \Delta u \rrbracket^{-1} & \\
\rightarrow 0 & \text { for }\|\Delta u\| \rightarrow 0
\end{aligned}
$$

then $\mathrm{I}\left(\mathrm{u}_{0}\right) \Delta \mathrm{u}$ is a Frechet derivative of an abstract function at a point $u_{0}$ that corresponds to increment of argument $\Delta \mathrm{u}$, and the final member is the error due to the discarded terms with powers $\Delta u$ greater than one.

Linear operator $\mathrm{I}(\mathrm{U})$ is usually denoted as $\mathrm{A}^{\prime}(\mathrm{u})$ and called Frechet derivative of nonlinear operator $A$ at the point $u$. Linear function $\mathrm{I}\left(\mathrm{u}_{0}\right) \Delta \mathrm{u}$ can be considered as G ateaux derivative which is defined by formula

$$
\mathrm{A}^{\prime}\left(\mathrm{u}_{0}\right) \Delta \mathrm{u}=\left.\frac{\mathrm{d}}{\mathrm{d} \lambda} \mathrm{A}\left(\mathrm{u}_{0}+\lambda \Delta \mathrm{u}\right)\right|_{\lambda=0}
$$

where $\lambda$ - is variable small parameter.

Thus, taking into account the accepted designations, Eq. (4) can take the form

$$
A\left(u_{0}+\Delta u\right)-A\left(u_{0}\right)=A^{\prime}\left(u_{0}\right) \Delta u+O(\|\Delta u\|)
$$

Therefore, taking into account Eq. (3), the approximate incremental equation takes the form

$$
A^{\prime}(u) \Delta u=\Delta p
$$


In order to transform this equation in a recurrent form, we introduce the notation for the number of sequential loading $n$, and obtain the incremental equation of the sequential load method

$$
A^{\prime}\left(u_{n}\right) \Delta u_{n+1}=\Delta p_{n+1} \quad(n=0,1,2,3, \ldots)
$$

If $E_{1}$ is an Euclidean space, and $E_{2}$ is an abstract space (general linear space), then $A$ mapping is called as an abstract function defined in $\mathrm{E}_{1}$ with range $E_{2}$. This function can be written in the form $y=f(x)$, which is adopted in mathematics and operator equation (1) takes the form $\mathrm{p}=\mathrm{Au}[9]$.

Considering operator equation (1) as an abstract function, we can obtain equation (6) by geometric construction.

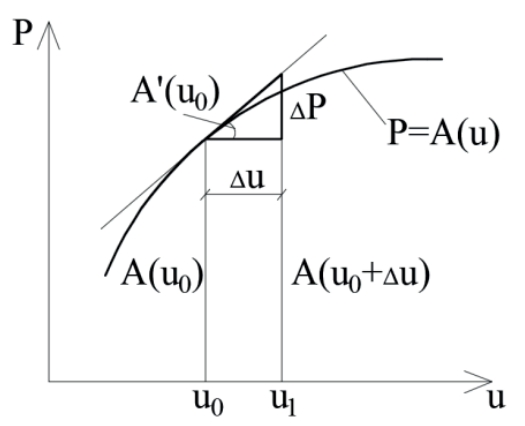

Figure 10
Figure 1 show that a continuous abstract function is replaced by some broken line as a result of the application of the sequential load method and the errors increase with an increase in the value of the load parameter. As follows from (5), the solution error can be regulated by decreasing the value of the loading step.

Let us consider another possibility of refining the solution obtained by the sequential load method. The total approximate solution obtained by the sequential load method at the $n^{\text {th }}$ stage of loading is denoted as $u_{n}$, where $n$ is the number of the load layer. When refining the solution, we take it as the zero approximation $u_{n}^{(0)}$.

In order to refine the solution at the achieved value of the total load $p_{n}=\sum_{n} \Delta p_{n}$, we consider the adjacent disturbed state $A\left(u_{n}^{(0)}+\Delta u_{n}, p_{n}\right)$. Subtracting the original one from it, we get the differential expression

$$
A\left(u_{n}^{(0)}+\Delta u_{n}, p_{n}\right)-A\left(u_{n}^{(0)}, p_{n}\right)
$$

Expanding it in a Taylor series in powers $\Delta u_{n}$, we get

$$
A\left(u_{n}^{(0)}+\Delta u_{n}, p_{n}\right)-A\left(u_{n}^{(0)}, p_{n}\right)=A^{\prime}\left(u_{n}^{(0)}\right) \Delta u_{n}+O\left(\left\|\Delta u_{n}\right\|\right)
$$

where the last term is the error of the order of the increment rate, arising due to the discarded terms with powers $\Delta u_{n}$ greater than one. K eeping only the linear term in expansion (9), we obtain the equation

$$
\begin{aligned}
& A\left(u_{n}^{(0)}+\Delta u_{n}, p_{n}\right)-A\left(u_{n}^{(0)}, p_{n}\right)=A^{\prime}\left(u_{n}^{(0)}\right) \Delta u_{n}(10) \\
& A\left(u_{n}^{(0)}+u_{n}^{*}-u_{n}^{(0)}, p_{n}\right)-A\left(u_{n}^{(0)}, p_{n}\right)=A^{\prime}\left(u_{n}^{(0)}\right)\left(u_{n}^{*}-u_{n}^{(0)}\right)
\end{aligned}
$$


This equation can be written like this

$$
A^{\prime}\left(u_{n}^{(0)}\right)\left(u_{n}^{*}-u_{n}^{(0)}\right)=A\left(u_{n}^{*}, p_{n}\right)-A\left(u_{n}^{(0)}, p_{n}\right)
$$

where $u_{n}^{*}$ is solution located closer to an exact solution than the initial approximation $u_{n}^{(0)}$. If the initial approximation $u_{n}^{(0)}$ is chosen close enough to the exact solution, then we can put $\mathrm{A}\left(\mathrm{u}_{n}^{*}, \mathrm{p}_{\mathrm{n}}\right) \approx 0$. Taking this into account, we obtain the equation

$$
A^{\prime}\left(u_{n}^{(k)}\right)\left(u_{n}^{(k+1)}-u_{n}^{(k)}\right)=p_{n}-A\left(u_{n}^{(k)}\right), \quad(k=0,1,2, \ldots)
$$

Equation (14) is written in full functions. If we introduce the notation $u_{n}^{(k+1)}-u_{n}^{(k)}=\Delta u_{n}^{(k+1)}$, where $\Delta u_{n}^{(k+1)}-$ is the change in the solution at the $\mathrm{k}+1$ iteration, and the solution in full func-

$$
A^{\prime}\left(u_{n}^{(0)}\right)\left(u_{n}^{*}-u_{n}^{(0)}\right)=-A\left(u_{n}^{(0)}, p_{n}\right)
$$

the structure of which allows you to organize an iterative process of approximation to the exact solution. For this purpose, it is necessary to enter the iteration number kinto this equation. We assume in equation $u_{n}^{(0)}=u_{n}^{(k)}, \quad u_{n}^{*}=u_{n}^{(k+1)}$, and as a result, at each iteration, taking into account (1), we will have the linear equation

$$
A^{\prime}\left(u_{n}^{(k)}\right) \Delta u_{n}^{(k+1)}=p_{n}-A\left(u_{n}^{(k)}\right), \quad(k=0,1,2, \ldots)
$$

where $\mathrm{k}$ is an iteration number, and $\mathrm{n}$ is a number of sequential load for which the initial approximation was chosen and the solution is refined. Equation (14) in full functions and equation (15) in incremental form have the form of equations of the Newton-Kantorovich method [3].

Operator equation (15) has the disadvantage that the Gateaux derivative $A^{\prime}\left(u_{n}^{(k)}\right)$ depends on the iteration number $k$ Therefore, in order to obtain each of the $k^{\text {th }}$ approximations, it is nec- essary to re-solve equation (15). If the initial approximation $u_{n}^{(0)}$ is chosen close enough to the desired solution, then, due to the continuity of the operator $A^{\prime}$, the elements $A^{\prime}\left(u_{n}^{(k)}\right)$ and $A^{\prime}\left(u_{n}^{(0)}\right)$ will differ little. On this basis, L.V. $\mathrm{K}$ antorovich proposed a modified method in which the sequence of approximations is determined from the solutions of the equations

$$
A^{\prime}\left(u_{n}^{(0)}\right) \Delta u_{n}^{(k+1)}=p_{n}-A\left(u_{n}^{(k)}\right), \quad(k=0,1,2, \ldots)
$$

where for all $k$, when we find all approximations, the same Gateaux derivative $A^{\prime}\left(u_{n}^{(0)}\right)$ is applied. Of course, the convergence rate of the modified method is lower, but L.V. K antorovich proved theorems on the uniqueness of the solution and the convergence of the modified method to this solution. 
The combination of two solution methods: the sequential load method and the Newton$\mathrm{K}$ antorovich method will be called the modified sequential load method, in which the initial approximation is constructed by the sequential load method, and the refinement is performed by the Newton-K antorovich method. It should be noted that in this case the procedure for choosing the initial approximation disappears, since the initial approximation $\mathrm{u}_{n}^{(0)}$ is the result of solving the problem at the end of the $\mathrm{n}^{\text {th }}$ stage of loading.

Thus, the implementation of the modified sequential load method for solving problems of nonlinear structural mechanics is carried out as follows. The lateral load acting on the structure is presented in the form of a set of rather thin layers, which sequentially load the structure under consideration.
At the first stage of loading, we solve the usual problem of linear structural mechanics. At the subsequent stages of loading, we solve the following equations

$$
A^{\prime}\left(u_{n-1}\right) \Delta u_{n}=\Delta p_{n}, \quad(n=1,2, \ldots)
$$

Figure 2 shows that increasing in the number of loading stages $\mathrm{n}$ leads to accumulation of the solution error due to linearization of the original equation (1). This can be reduced by decreasing the value of the load increment (curves 1, 2). However, this increases the number of loading stages and the complexity of the solution. In addition, it is necessary to separately decide on the choice of the value of the load increment.

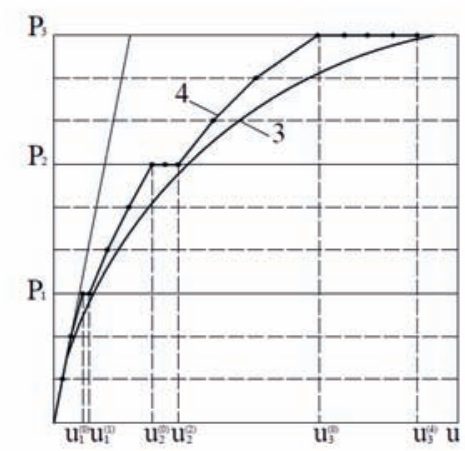

Figure2

At the end of each $\mathrm{n}^{\text {th }}$ loading stage or after several loading stages, the linearization error is reduced by the Newton-K antorovich method (15) or its modification (16), in which the value $u_{n}^{(0)}=\sum_{n} \Delta u_{n}$ obtained at the end of the $n^{\text {th }}$ loading stage is taken as the initial approximation. N ote, when we refine the solution, the iteration number $k$ increases, while the number of the loading step n remains constant.

The solution refined by the Newton-K antorovich method at the $\mathrm{n}^{\text {th }}$ stage of loading is taken as an initial approximation for further solution by the sequential load method. Note, when we refine the solution, only the number of the loading step $n$ increases, while the iteration number $\mathrm{k}$ remains constant. After the implementation of several or each of the sequential loads, the solution is refined by the Newton-K antorovich method (see Fig. 2, curve 4). The value of sequentially applied load layers can be significantly increased and it can be changed in the process of solving depending on the features of the problem being solved. This reduces the complexity of obtaining a solution. Boundary value problems are realized by wellknown methods for solving linear equations.

\section{REFERENCES}

1. Vlasova L.A., Zarubin V.S., Kunyrkin G.N. Priblizhennyye metody matematicheskoy fiziki [Approximate methods of 
mathematical physics]. Moscow: Publishing of MGTU named after N.E. Bauman, 2001. - 700 p.

2. Il'yushin A.A. Plastichnost' [Plasticity]. M Oscow - Leningrad: OGIZ. 1948, ch. 1.

3. Petrov V.V. K raschetu pologikh obolochek pri konechnykh progibakh [Calculation of shallow shells with finite deflections]. - Nauchnyye doklady vysshey shkoly. Stroitel'stvo [Scientific reports of higher education. Construction], 1959, No 1.

4. Petrov V.V. M etod posledovatel'nykh nagruzheniy $\mathrm{v}$ nelineynoy teorii plastinok i obolochek [The sequential load method in the nonlinear theory of plates and shells]. Publishing of Saratov State U niversity, 1975.

5. Petrov V.V., Ovdhinnikov I.G., Yaroslavskiy V.I. Raschet plastinok i obolochek iz nelineyno-uprugogo materiala [Calculation of plates and shells made of nonlinear elastic material]. Publishing of Saratov State University, 1976.

6. Petrov V.V. N elineynaya inkremental 'naya stroitel'naya mekhanika [Non-linear incremental building mechanics]. - M oscow: Infra-Inzheneriya, 2014. - $480 \mathrm{p}$.

7. Petrov V.V. Nelineynaya stroitel'naya mekhanika [Non-linear construction mechanics]. M oscow: Publishing A SV , 2019. - 432 p.

8. Srubshchik L.S. Vypuchivaniye i poslekriticheskoye povedeniye obolochek [Buckling and post-critical behavior of shells]. Publishing of Rostov State University. 1981.

9. Lyusternik L.A., Sobolev V.I. Elementy funktsional 'nogo analiza [Elements of functional analysis]. Publishing "Nauka". M oscow 1965.
10. Kantorovich L.V., Akilov G.P. Funktsional'nyy analiz [Functional analysis]. M oscow, Nauka, 1977.

\section{СПИСОК ЛИТЕРАТУРЫ}

1. Власова Л.А., Зарубин В.С., Кувыркин Г.Н. Приближенные методы математической физики. М.: Изд-во МГТУ им. Н.Э. Баумана, 2001. - 700.

2. Ильюшин А.А. Пластичность. М. - Л. ОГИЗ. 1948, ч. 1.

3. Петров В.В. К расчету пологих оболочек при конечных прогибах. - Научные доклады высшей школы. Строительство, 1959, №1.

4. Петров В.В. Метод последовательных нагружений в нелинейной теории пластинок и оболочек. Изд-во Саратовского ун-та, 1975.

5. Петров В.В., Овчинников И.Г., Ярославский В.И. Расчет пластинок и оболочек из нелинейно-упругого материала. Изд-во Саратовского ун-та, 1976.

6. Петров В.В. Нелинейная инкрементальная строительная механика. - М.: Инфра-Инженерия, 2014. - 480 с.

7. Петров В.В. Нелинейная строительная механика. Изд-во АСВ. М. 2019. - 432 с.

8. Срубщик Л.С. Выпучивание и послекритическое поведение оболочек. Изд-во Ростовского ун-та. 1981.

9. Люстерник Л.А., Соболев В.И. Элементы функционального анализа. Изд-во «Наука». М. 1965.

10. Канторович Л.В., Акилов Г.П. Функциональный анализ. М. Наука, 1977.
Vladilen V. Petrov, full member of the R ussian A cademy of A rchitecture and Construction Sciences (RAASN), Doctor of Technical Sciences, Professor of the Department of Theory of Structures and Building Structures, Saratov State Technical U niversity named after Y . Gagarin; 410054, Russia, Saratov, st. Polytechnic, 77; Tel. +7 (909) 388-41-20; e-mail: vvp@sstu.ru, vladilen307@gmail.com
Петров Владилен Васильевич, академик Российской академии архитектуры и строительных наук (PA$\mathrm{ACH})$, доктор технических наук, профессор кафедры «Теория сооружений и строительных конструкций» Саратовского государственного технического университета имени Гагарина Ю.А.; 410054, Россия, г. Саратов, ул. Политехническая, 77; тел. +7(909)388-41-20; e-mail: vvp@sstu.ru,vladilen307@gmail.com 